\title{
Views, Achievements and Implementation of Preschool Teachers Regarding Movement Education Workshop*
}

\author{
A. Dilsad Mirzeoglu ${ }^{1}$, Figen Altay $^{2}$, Sumeyra Sert Agca $^{3}$ \\ ${ }^{1}$ Faculty of Sports Science, Sakarya University, Sakarya, Turkey \\ ${ }^{2}$ Faculty of Sports Science, Hacettepe University, Ankara, Turkey \\ ${ }^{3}$ The Ministry of Education, Bolu, Turkey \\ Correspondance: A. Dilşad Mirzeoglu, Faculty of Sports Science, Department of Teaching Physical Education and \\ Sport, Sakarya University, 54187 Serdivan, Sakarya, Turkey.
}

Received: April 11, 2017

Accepted: May 11, 2017

Online Published: May 15, 2017

doi:10.11114/jets.v5i6.2344

URL: https://doi.org/10.11114/jets.v5i6.2344

*This paper was presented in "Global Forum 2016 for Physical Education Pedagogy”, May 26-28, Ankara, Turkey.

\begin{abstract}
The aim of this study was to determine the views, achievements and actions of preschool teachers regarding the workshop on movement education. In this study qualitative research design and action research approach were used. The participants comprised 10 voluntary female preschool teachers working in the Central district of Bolu province. In order to collect data, the drawings of the participants, open-ended questions and focus group interviews were used. Content analysis technique was used on the analysis of data obtained in the study. According to the findings, the preschool teachers thought that the attendance of workshop improved self-development. Teachers stated that workshop caused the improvement of their knowledge, skills and self-confidence about movement education and help them to overcome the problems they experienced with teaching this subject. However, they determined that with the use of more gross muscle activity in class and outdoor space (garden), they could design a variety of activities and materials, and stated that in this way the students would also become more active individuals. Another important effect of the workshop on the teachers was the encouragement of the teachers to collaborate between the members of their own professional group in the creation of the activities. Thus, this kind of workshops should be seen as important for preschool teachers and should become prevalent in their practice.
\end{abstract}

Keywords: movement education, preschool education, fundamental movement skills, physical activity cards

\section{Introduction}

Physical activity is important in developing and maintaining good health in children, which can have a significant influence on the quality of their lives in later years. Adults who participated in various physical activities as young children are more likely to be active and participate in sports activities as compared to those who did not participate in this way (Gallahue \& Ozmun, 1998; Haywood \& Getchell, 2009; Robinson \& Goodway, 2009; cited in Sevimli-Çelik \& Johnson, 2013). The importance of motor skill development programs during preschool period is controversial because of the lack of teachers' understanding and competences. Therefore, the important role of understanding movement competency for the protection active and healthy life style (Hands, Parker \& Larkin, 2001) and supporting well-planned and effective programs for children in early childhood period is especially significant. This is vital because movement education implementation is the least used educational activity area in preschool education. Sallis and colleagues, for example, observed 33 preschool children at play for 30 minutes and found that only $11 \%$ of that time was spent in vigorous activity. The available evidence is not encouraging. The participation rate of children in organized sport and physical activity ranges from 32\% for 5-year-olds to $69 \%$ for those aged 11 years (cited in Australian Bureau of Statistics [ABS], 2000). Physical activity guidelines recently released (Corbin \& Pangrazi, 1998; National Association for Sport and Physical Education [NASPE], 2002) recommend that all children from birth onwards engage in developmentally appropriate physical activity. Children in preschool should participate in at least 60 minutes of structured and between 60 and 180 minutes of unstructured physical activity everyday. They should not be sedentary for more than one hour at a time (except when sleeping) and develop competence in fundamental movement skills (NASPE, 2002; cited in Hands \& Martin 2003). 
Fundamental movement skills (FMSs), which are necessary for the early childhood, are best categorized into three groups; body management, locomotors and manipulative. Many skills can be included in these groups. Body management skills involve balancing the body while standing still in motion. Locomotors skills involve moving the body in any direction from one point to another. Manipulative (object control) skills require controlling implements (bats, racquets or hoops) or objects (balls) either by hand or foot (Department of Education Western Australia, 2013). Fundamental movement skills and movement concepts constitute movement education.

For children in the preschool, appropriate environments and experiences should be provided for the development of movement as it is in other areas. However, there are very limited movement opportunities for children living in a home environment, especially in urban areas (Özyürek, Özkan, Beğde \& Yavuz, 2015). Because of this reason, the opportunities of movement education for children at this age is extremely important. The aim of movement education is to prevent children from feeling unsuccessful as a result of low movement skills, and to improve their confidence by enjoying success in this area (Graham, Holt/Hale \& Parker, 2009).

However, the majority of preschool teachers supported physical activity in preschool period, but they admitted that they had limited knowledge and little competency to teach physical activities. (Sevimli-Çelik \& Johnson, 2013; Sert, 2016). Sevimli-Çelik \& Johnson (2013) stated in their study that $61 \%$ of the teachers were aware that their knowledge and competency in this area was limited and thus requested professional development opportunities relating to early childhood physical activities. In addition, the result of another study showed that preschool teachers did not confident enough to have children do physical activities and they indicated that they needed in-service training about movement education. Additionally, only three percent of the pre-school teachers felt that the movement education they received at university was sufficient (Sert, 2016).

Korkmaz Haş1 \& Erol (2004) stated that the preschool teachers preferred indoor games in general, and they included muscle coordination and balance movements by gross motor skills of children during games. However, they did not use materials such as balls, ropes, etc. in games. Sert (2016) stated that preschool teachers did not spend enough time for movement education and they were able to do only a limited number of activities during classes. Sevimli (2008) indicated that movement education practices were not aligned with physical education goals for these schools. Children's participation in organized sport activities is valued more as an extracurricular activity by administrators and parents. Limited indoor/outdoor spaces for movement activities seem to be among the limiting factors for movement education practices. Structured play and movement activities were not seen as an academic activity by administrators and parents and were perceived as free play, and-not connected to FMSs.

In Turkey, after the revision of the curriculum for primary and secondary schools in 2012, physical activity cards (PACs) were developed as an aid to class and physical education teachers for physical education and sport lessons (Ministry of National Education [MNE], 2012).The purpose of the development of these cards was to enrich children's and youth's lives with games, sport and physical activities. PACs consist of two sets as in the original TOPs cards. The first set of the cards (yellow card group), is appropriate for the developmental characteristics of 5-9 years old children, consists of fundamental movement skills and knowledge. In the second set (purple card group), is appropriate for 10-13 years old children, and these cards serve for developing basic sportive skills which children need to have in the beginning stage of any branches of sports (http://www.uluslararasiilham.org.tr/site/?page_id=82, February11, 2013).

The first set of PACs (yellow card group) contains the fundamental movement skills needed by preschool children. For this reason, it is desirable to organize a workshop for including the promotion of PACs containing fundamental movement skills and movement concepts, and to examine the influence of this workshop. Therefore, the aim of this study was to determine the views, achievements and implementations of preschool teachers regarding the workshop on FMSs.

\section{Method}

\subsection{Research Design}

Qualitative research design and action research approach (liberating/improving/critical) were used. It is important in action research that "every environment is unique" and to understand the involvement of participants in this manner. Participants can be directly observed in their natural environment and they should contribute to the study by being open about their experience with the researcher. In such an ongoing process of problem solving, there will be an intense interaction and sharing between researchers and practitioners (Yıldırım \& Şimşek, 2005: 295).

\subsection{Participants}

The participants comprise 10 female preschool teachers working in the Central district of Bolu province during 2014-2015 academic year, spring semester. 5 of the participant teachers $(50 \%)$ graduated from the open education faculty, and the others (50\%) graduated from formal education institutions. The teachers who participated in the study had $9.3 \pm 2.83$ years of average professional experience. 


\subsection{Collecting Data}

In order to collect data the drawings of the participants, open-ended questions and also focus group interviews (FGIs) were used. Research was conducted from the beginning till the end by the researchers themselves as a "participant observers". Moreover, the researchers as practitioners observed the participating teachers during the workshop.

After the 14-hour workshop, semi-structured focus group interviews (FGIs) were done by participating teachers in order to determine the effects of the workshop each month by one of the researchers lasting 2-2.5 hours. The interviews were held three times ( 3 months) in one month intervals to express their views and achievements about workshop and to test the ongoing effect of the workshop. FGIs were held in a setting where the teachers felt comfortable, and the teachers were asked questions such as "What did you do about the movement education you applied since the workshop until today?", "What has changed about your implementations regarding motor learning field?", "What are the contributions (achievements) of the workshop to your students and to you personally?", "What were the problems you faced during your implementations and how did you solve them?", and "What are your commitments and wishes for the following month?". The researcher recorded the answers of the teachers as short notes and at the same time tape recorder was used to prevent data loss.

Background of the Researchers: One of the researchers is an expert who completed her $\mathrm{PhD}$ in the field of Curriculum Development and Instruction, and has been a faculty at The Department of Teaching Physical Education for 21 years. She has conducted theoretical and practical lessons in her field of study for 15 years, and is an experienced expert in the field of teacher education. Furthermore, this researcher was a physical education teacher in an elementary school for two years at the beginning of her professional career.

The second researcher who participated in the workshop completed her PhD in the field of Physical Education and Sports and has been a faculty member at the Department of Physical Education and Sports Teaching for 25 years. She has been conducting theoretical and practical lessons in her field of study for 20 years. At the same time, both researchers who participated in the study were also members of the commission that was formed for preparation of Physical Activity Cards (PACs), and they are experts in teaching fundamentals movement skills to teachers who are in the field at different levels concerned with the cards.

\subsection{Workshop Processing Procedure}

At the beginning of the workshop, required permissions for teachers who would participate in the workshop were arranged and voluntary participation was provided. Then, the information of the workshop was presented to the participants by the researchers. Table 1 shows the action plan of the workshop in detail. 
Table 1. Action Plan Regarding the Workshop Processing

\begin{tabular}{ll}
\hline Duration & Implementation Phases \\
\hline Phase 1 & * Introduction speech \\
(15 Min.) & * Key questions- \\
& *Presentation of materials \\
& *Use of space \\
& *Motivation speech \\
& \\
& \\
\hline Phase 2 & *Warming \\
(30 & (Exploration of the game and preparation) \\
Min.) & *drawing the pictures of the game \\
& *Introduction of movement education
\end{tabular}

$\begin{array}{ll}\text { Phase } 3 & \text { *Introduction of physical activity cards } \\ \text { (45 Min.) } & \text { (PAC) } \\ \text { Phase } 4 & \text { *Introduction and implementation of loco } \\ \text { (3 hours) } & \text { motor movements }\end{array}$

Phase 5 *Introduction and implementation of

hours)

Phase 6 *Introduction and implementation of (3 hours) manipulative movements

$\begin{array}{clc}\text { Phase } 7 & \text { *Implementations } & \text { about musical } \\ (1.5 & \text { activities/games } & \end{array}$

hours)

Phase 8 *Introductions and implementations

( 2 hours) about combined movements and trail work

\section{Implementation Details}

-Giving an introduction to the participants

(Why are we here, what are we going to do, why and how, etc).

- Taking the permissions

- Explanation of the workshop objectives

- Emphasizing the importance of the objective

- Presenting the materials (PACs and application materials) to be used in the workshop

-Explanation of significant points in material selection

- Description and arrangements for the effective use of the space

- Using music for motivation and providing a warm atmosphere

-Explanation

-Introduction (requesting the participants to consider games and activities that they make the children at the age groups of 3-4 and 5-6 perform with pictures)

-Requesting from the participants to write down what the movement education is and the problems faced in classroom during movement education implementations

-Examining of physical activity cards as a group

-Preparation of cards by each group at the end of the allowed time

-Implementing of loco motor movements individually and in pairs from PACs

-Having the other groups make paired loco motor movements by preschool teachers

- Implementing of balance movements individually and in pairs from PACs

- Having the other groups make paired balance movements by preschool teachers

- Implementing of manipulative movements individually and in pairs from PACs

- Having the other groups make paired manipulative movements by preschool teachers

- Implementing of examples of musical activities/games individually and in pairs

- Having the other groups make examples of musical activities/games in pairs by preschool teachers

- Implementing of examples about combined movements from PACs and trail works individually and in pairs

-Having the other groups make combined movement cards in pairs by preschool teachers

\subsection{Data Analysis}

A Content analysis technique was used for the analysis of data obtained from drawings, open-ended questions and focus group interviews. Data was processed and transcribed into a word document. In the next step, data and statements were coded within expressed statements in short sentences by two experts who are experienced in qualitative researches and dissertation/thesis (as supervisor/advisor). During the coding overlapping statements were grouped as themes. The preschool teachers ' opinions on the statements related to themes were presented in the study findings as T1, T2, etc.

\subsubsection{Validity and Reliability}

Validity: The findings were arranged to gather meaningful and consistent data. This data was coded by two researchers and the consistency between the two codes was checked and formed as a whole. The data obtained in this study was coded by the researcher herself and the second researcher who is an instructor at the university. Furthermore, both of the researchers participated during the workshop process and they had knowledge about the aim and the method of the study.

Reliability: Researchers clearly defined the methods and stages of the study. The data collection procedure was clearly described as well as those related to processing, analysis, interpretation, and how results were achieved. Findings were clearly linked to the expressed opinions. During data analysis bias and misunderstandings were revised and consequently invalid data was extracted and excluded.

The statements in the study were read and encoded independently by both of the researchers and themes were created. To calculate the reliability of the two researchers' codes and themes, the Miles \& Huberman's (1994) formula was applied. As a result, the agreement for two researchers for the total statements from three focus group discussions was 49 and the disagreement in 15. According to Miles \& Huberman's (1994) formula the correspondence percentage was 
calculated as $76.6 \%$. Since the correspondence percentage is more than $70 \%$, the research is accepted as reliable.

Triangulation: Data was obtained by different data collection techniques and variation of the data was provided.

\section{Results}

The data obtained from the results of drawings, open-ended questions and FGIs based on the analysis of research questions are shown below respectively.

\subsection{Activities and Games Which Preschool Teachers Applied in the Class Prior to the Workshop}

At the beginning of the workshop preschool teachers were asked to describe the activities and games they made the children of 3-4 and 5-6 years of age perform in their classes through drawings. After analysis of the drawings the following results were derived.

Table 2. Games/Activities and Materials of the Preschool Teachers Made the Children at Different Age Periods

\begin{tabular}{lll}
\hline Age Group & Games/Activities & Materials \\
\hline & Walking/running (fast-slow) (5 persons) & Obstacles of various sizes \\
& Jumping with double feet (5 persons) & Mats \\
& Rolling (4 persons) & \\
Crawling (3 persons) & \\
& Throwing to the target/catching (3 persons) & \\
3-4 years of age & Jumping/passing the bar (3 persons) & \\
& Imitation walking (2 persons) & \\
& Turning (1 person) & Balls \\
& Gymnastic movements on the floor (1 person) & Mats \\
& Squatting, standing up (1 person) & Ropes \\
& Walking (fast/slow-on toes) (4 persons) & Hoops \\
& Single/double feet jumping (8 persons) & Ribbons \\
& Throwing to the target/catching (6 persons) & Music player \\
& Rope jumping (4 persons) & Obstacles \\
& Running (3 persons) & \\
Rolling/somersault (2 persons) & \\
Paired/group studies (3 persons) & \\
Trail working (2 persons) & \\
& Hula hoop turning (1 person) & \\
& Climbing up stairs/coming down stairs (1 person) & \\
Connecting and solving ribbon (1 person) & \\
B-6 years of agames (1 person) & \\
& Musical plays/rondos (2 persons) & \\
\hline
\end{tabular}

The preschool teachers stated that for children of 3-4 years of age they generally had them perform locomotors movements with no set rules that they could do individually; for children 5-6 years of age they made them play simple games with very easy rules. An important point is that the drawing activity the teachers used few materials both for the 3-4 year old children as well as for those who were 5-6 (Table 2).

\subsection{Opinions and Barriers about the Movement Education Prior to the Workshop}

At the beginning of the workshop, the preschool teachers were asked, "What is movement education?" and "Indicate 3 problems you faced in activities/games directed to motor development field in your classrooms", and note the written answers you received. Preschool teachers defined movement education as activities that provided physical development while at the same time helping the child's spiritual and emotional development. They noted as well that movement education supported large-small muscle development, activities with and without equipment and providing hand-eye coordination as well as instilling a recognition of the body as an entity. The statements: "Movement education is a systematic education requiring hand-eye coordination and supporting large-small muscle development" (T1) and "They are physical activities made for supporting large and small muscle development physically and applied with and without equipment" (T8) emphasize that movement education consisted of the development of both hand-eye coordination, large-small muscle development and activities made with/without equipment. Nevertheless, a statement related to providing spiritual and emotional development of children was: "Movement education stimulates body movement and at the same time assists in the positive development of spiritual and emotional development" (T3).

When the answers of the preschool teachers to the question "What are the problems you face in movement education implementations?" were analyzed, the answers were as follows: "inefficient physical conditions", "material deficiency", "limited knowledge and little competency to teach physical activities" and "children's short attention span". 


\subsection{Findings Related to Movement Education after the Workshop}

After the workshop, three FGI were conducted with the preschool teachers after an interval of one month. In these interviews, the teachers were asked the question "What have you done about the movement education implementations since the workshop you participated in?" The answers obtained from the teachers' views are listed thematically in Table 3.

Table 3. The Themes Obtained for Those Made Regarding Movement Education

\begin{tabular}{|c|c|c|}
\hline Themes Obtained in the First FGI & Themes Obtained in the Second FGI & Themes Obtained in the Third FGI \\
\hline Using PACs (All teachers) & $\begin{array}{l}\text { Using PACs (T1, T2, T3, T4, T5, T6, T7, } \\
\text { T10) }\end{array}$ & Using PACs (All teachers) \\
\hline Continues network (All teachers) & Continues network (All teachers) & Continues network (All teachers) \\
\hline $\begin{array}{l}\text { Increasing in activity time, number and } \\
\text { variety }(\mathrm{T} 1, \mathrm{~T} 4, \mathrm{~T} 5, \mathrm{~T} 6, \mathrm{~T} 7, \mathrm{~T} 8, \mathrm{~T} 10)\end{array}$ & $\begin{array}{l}\text { Continuation of movement education (All } \\
\text { teachers) }\end{array}$ & $\begin{array}{l}\text { Continuation of movement education (T2, } \\
\mathrm{T} 3, \mathrm{~T} 4, \mathrm{~T} 7, \mathrm{~T} 9)\end{array}$ \\
\hline $\begin{array}{l}\text { Using material (T2, T4, T5, T6, T7, T8, } \\
\text { T9, T10) }\end{array}$ & Using material (T1, T3, T5, T7) & $\begin{array}{l}\text { Using different materials (T2,T3, T4, T5, } \\
\text { T6, T7, T8, T9, T10) }\end{array}$ \\
\hline \multirow[t]{3}{*}{$\begin{array}{l}\text { Informing the required persons }(\mathrm{T} 2, \mathrm{~T} 4 \text {, } \\
\mathrm{T} 6, \mathrm{~T} 7, \mathrm{~T} 10)\end{array}$} & $\begin{array}{l}\text { Informing the required persons }(\mathrm{T} 3, \mathrm{~T} 6 \text {, } \\
\mathrm{T} 7)\end{array}$ & \\
\hline & $\begin{array}{l}\text { Rhythm education and dancing (All } \\
\text { teachers) }\end{array}$ & $\begin{array}{l}\text { Rhythm education and dancing (T1, T3, } \\
\text { T4, T7) }\end{array}$ \\
\hline & Different games (T1, T4, T8) & \\
\hline
\end{tabular}

In each three FGI, the teachers were asked the question of "What have you done about the movement education implementations since the workshop until now?" and all teachers gave the answer like "I downloaded Physical Activity Cards (PACS) in the internet and am using them". T10 and T5 expressed this situation as, "I continuously look at the yellow cards. It is like warming up and getting ready for a game, and then we perform the activities and game" (T10 in the second FGI) and "PACs are guiding. I create different activities from them" (T5 in the third FGI). Another opinion received from all teachers on this question is "We established continuous network over social media". T7 expressed this situation in the first FGI as "We established a social network group (WhatsApp) after the workshop. We keep in touch with friends, and share pictures, activities, videos and different opinions. We obtain ideas there a lot".

The teachers stated the most important impact of in the first FGI workshop was that "I have increased the time, number and variety of the activities in motor field"; this opinion was expressed in the second and third FGIs as the theme of "Continuation of the movement education". T5 explained this effect in the first FGI as "I can vary the activities very easily now. With gallop, sliding, etc..." T2 explained in the third FGI as "I used to do it for 5-10 minutes. Now we do it every day for 30 minutes". The teachers expressed opinion in each three FGIs about this question as "I prepared new material to apply in motor field". For example in the first FGI, T2 expressed opinion as, "I made circles by cutting plastic plates. I cut the coke bottles and painted them. I made a bowling game from the same coke bottles and used them to form a space, to create obstacle tracks". Another effect that was not asked of the teachers but was however an expectation was to inform others at their schools about the training they received. The teachers stated in the first and second FGIs that "I informed my group friends/administrators". In addition, the teachers in general noted that in the second and third FGIs that "The amount of movement education decreased, and the amount of rhythm and dance increased." T8 explained this situation in the second FGI as "I apply it 3 days a week for half an hour. But these are mostly musical plays, dances and rondo recording studies".

\subsection{Findings on the Changes about the Implementations Regarding Movement Education}

In the three FGI, the question of "What has changed in your implementations regarding motor learning field?" was asked to the teachers and the themes are shown in Table 4.

When the answers collected on motor learning were analyzed, the common themes in each three discussions were "using outdoor space (garden and trails) for various activities which stimulated gross (large) muscle groups". T1 stated opinion about these themes in the first FGI: “...Then, we established trails. I tried to do different activities. Now they (the students) create the trails themselves. They like working with trails..." and T5 stated that "We used to be afraid to go to the garden because of safety reasons, but now the usage of our garden has increased". T9 stated in the second FGI about the musical game implementations "I am teaching the penguin dance for the April $23^{\text {rd }}$ holiday. If hadn't received movement education training, I wouldn't have dared to have children preform this dance".

Another theme obtained from the replies of the teachers is the value of an interdisciplinary approach. T5 said in the first FGI about this theme that "We had them perform activities involving the five sense organs. For example, in order to teach the numbers, they draw the numbers, paint and do them. I tell them you get up and jump 7 times. I tell them to touch hands of 7 friends, etc".

In the first FGI, the teachers expressed the opinion with regard to this question that they use movement concepts (MCs) more effectively. According to this result, it can be said that the workshop was effective in a deeper understanding and 
using of MCs that are especially absent in the teachers. T6 stated about this finding that "I started first of all in the safe space, general and self-space like my colleagues did and we succeeded. I explained them in every aspect. In the car, their lives, and in the classroom, etc..."

Table 4. The Themes Obtained Regarding Changes in the Implementations in Movement Education

\begin{tabular}{|c|c|c|}
\hline Themes Obtained in the First FGI & Themes Obtained in the Second FGI & Themes Obtained in the Third FGI \\
\hline $\begin{array}{l}\text { Using outdoor space (garden) (T4, T5, } \\
\text { T6, T7, T8) }\end{array}$ & $\begin{array}{l}\text { Using outdoor space (garden) (T2, T5, } \\
\text { T9) }\end{array}$ & Using outdoor space (garden) $(\mathrm{T} 2, \mathrm{~T} 4)$ \\
\hline Trail works $(\mathrm{T} 1, \mathrm{~T} 3, \mathrm{~T} 5)$ & $\begin{array}{l}\text { Various and difficult activities (All } \\
\text { teachers) } \\
\text { Using different materials (T2, T5, T7, } \\
\text { T10) } \\
\text { Musical games (T2, T4, T7,T9) }\end{array}$ & $\begin{array}{l}\text { Gross (large) muscle activities (T2, T7, } \\
\text { T8) } \\
\text { Using different materials (T1, T3, T4, T6) } \\
\text { Musical games (T1) }\end{array}$ \\
\hline Interdisciplinary approach (All teachers) & $\begin{array}{l}\text { Interdisciplinary approach }(\mathrm{T} 3, \mathrm{~T} 5, \mathrm{~T} 7, \\
\mathrm{T} 8)\end{array}$ & Games with rules $(\mathrm{T} 2, \mathrm{~T} 4)$ \\
\hline $\begin{array}{l}\text { Effective concept usage (All teachers) } \\
\text { Games including moving (T2,T4, T5, T7, } \\
\text { T9, T10) } \\
\text { Working planned and target based } \\
\text { (T1,T2, T3, T5, T8, T10) } \\
\text { Using open-ended materials (T2, T5, T6, } \\
\text { T7, T9, T10) }\end{array}$ & Participation $(\mathrm{T} 3, \mathrm{~T} 8, \mathrm{~T} 10)$ & Participation (All teachers) \\
\hline
\end{tabular}

the Achievements of the Workshop

The third question was "What are the achievements of the workshop for your students and you personally?". The themes obtained are shown in the Table 5.

Table 5. The Themes Obtained About the Achievements of the Workshop

\begin{tabular}{|c|c|c|}
\hline Themes Obtained in the First FGI & Themes Obtained in the Second FGI & Themes Obtained in the Third FGI \\
\hline Thinking about project (All teachers) & Thinking about project(T7) & Thinking about project (All teachers) \\
\hline $\begin{array}{l}\text { Awareness and consciousness(All } \\
\text { teachers) }\end{array}$ & $\begin{array}{l}\text { Awareness and consciousness (T1,T3, } \\
\mathrm{T} 4, \mathrm{~T} 5, \mathrm{~T} 7, \mathrm{~T} 8, \mathrm{~T} 9)\end{array}$ & $\begin{array}{l}\text { Awareness and consciousness (All } \\
\text { teachers) }\end{array}$ \\
\hline \multirow[t]{3}{*}{ Being active (All teachers) } & Being active (All teachers) & \\
\hline & Self-confidence (T7, T9) & Self-confidence (T1,T3, T6) \\
\hline & Creativity (T2, T3, T7, T9, T10) & Creativity (T1, T4, T5, T6, T7, Ö9) \\
\hline $\begin{array}{l}\text { Improvement in teacher competence } \\
\text { (using PACs, class management, etc.) } \\
\text { (T1, T2, T4,T5, T8, T9) }\end{array}$ & & Class management (T2, T3,T5, T6, T8) \\
\hline \multirow[t]{6}{*}{$\begin{array}{l}\text { Producing of activity and material (All } \\
\text { teachers) }\end{array}$} & & $\begin{array}{l}\text { Producing activities (T1, T2, T4, T5, T9, } \\
\text { T10) }\end{array}$ \\
\hline & Happiness (All teachers) & Happiness (T7, T8, T10) \\
\hline & & $\begin{array}{l}\text { Measurement and evaluation (T3, } \\
\mathrm{T} 5, \mathrm{~T} 7, \mathrm{~T} 9)\end{array}$ \\
\hline & Using game (T1,T2, T3,T6,T9) & \\
\hline & Practicability (T6) & \\
\hline & STUDENTS & \\
\hline \multirow[t]{2}{*}{ Happiness (T3, T4,T6, T9) } & Happiness (All teachers) & Happiness (T7, T8, T10) \\
\hline & Movement concepts(All teachers) & Movement concepts $(\mathrm{T} 1, \mathrm{~T} 2)$ \\
\hline
\end{tabular}

Willingness in participation (T1, T2, T5,

$\mathrm{T} 7, \mathrm{~T} 8, \mathrm{~T} 10)$

Obeying the rules $(\mathrm{T} 3, \mathrm{~T} 4)$

Energy expenditure (T8, T10)

The common themes obtained from each of the three FGIs about this question were "Thinking about project, improvement of awareness and consciousness", and it was "happiness" for the students. All teachers expressed producing projects about the implementations in their classes after the workshop in the three FGI. For example, T7 expressed her desire in the second FGI as "I started to think about projects a lot. I think about the materials. Such a project is possible by producing new materials from open-ended materials". Nevertheless in all three interviews, the teachers emphasized that the workshop was beneficial for improving their awareness and becoming conscious about motor field and teaching that issues and this could be perceived as the most important achievement of the workshop by the teachers. T3 expressed opinion in the second FGI about the matter as "We really were not aware of it previously. Now we are aware and we get better results from everything we do, because we are conscious now". 
The teachers expressed the themes "being active, self-confidence, creativity, improvement in teacher competency (the usage of PACs, class management, etc.), happiness and ability to produce activities" that explain their other achievements in only two FGIs. T8 said about being active in the first FGI that "Both I got activated and as class we got activated," and T7 said in the second FGI "There was a little activation in my life but it increased even more. There were more steps in my pedometer now, the steps increased because we played games outside with the children...". T2 said about the theme self-confidence in the second FGI, "We are now stop and think when we don't do it. Why didn't I do movement education today? I began to feel lack of movement education. I have developed consciousness and self-confidence about movement education". Moreover, the teachers indicated improvement in teaching competency as another achievement of the workshop for them. T8 stated in the third FGI about this achievement "My competency in group games improved in terms of class control and giving instructions". In addition, the teachers and their students joined in focusing on the happiness theme. T9 emphasized in the second FGI that "Now I am more active in the classroom...I saw that the kids are happier and get up from their desks". In addition to all of these achievements, the teachers indicated that they can now produce activities more easily. T10 summarized this theme in the third FGI as "I made additions to the old games I know. I used my own creativity as well. I think that I became more aware of games that were easier and more functional".

The achievements of the children about the question based on the views of the teachers were determined as "happiness, learning and using of movement concepts and energy expenditure". T2 stated in the second FGI about especially the movement concepts that "We use them (concepts) when we vary the games. For instance, work as individually, in pairs, in a group. We use the concepts of right and left. There is jump to the front-jump to the back."

\subsection{Results about the Experienced Problems and Solution Ways}

Another question asked to the teachers was "What are the problems you face about your implementations in the classroom and how did you solve them?". The themes obtained from the teachers' opinions are shown in the following table.

Table 6. The Themes Obtained Regarding Experienced Problems and Solution Ways

Themes Obtained in the First FGI Themes Obtained in the Second FGI Themes Obtained in the Third FGI

Space problem (T3, T4, T6) $\quad$ Space problem (T3, T6) No problem (All teachers)

Problem about material supply (T2, T4,

T5, T6, T7)

\section{SOLUTION WAYS}

Creativity (T2, T4, T7)

Creativity (T2,T3, T7, T9, T10)

Creativity (T3,T4, T5, T8, T9)

Problem solving (All teachers)

Problem solving (T2, T3, T5)

The common theme obtained on the problems issue in the first and second FGIs was an "space problem", and the teachers agreed on the themes "problem solving and creativity skills" as the solution of this problem. T3 stated that there was a "space problem" in the first focus FGI however they showed their creativity as "I told the administration. I removed the centers in the classroom, for instance. I removed them, and I moved them to the base of the walls", and T2 said that "We are trying to produce. We try to find a solution ourselves for each of our problems, without finding an excuse".

\subsection{Results on Commitments, Views and Wishes}

The last question directed to the teachers was "What are your commitments and wishes for the next month?" and in the third focus group interview, the question was "What are your views and suggestions about this study?". The themes obtained as a result of the views of the teachers are shown in Table 7. 
Table 7. The Themes Obtained About the Commitments and Wishes

\begin{tabular}{lll}
\hline $\begin{array}{l}\text { Themes Obtained in the First } \\
\text { FGI }\end{array}$ & Themes Obtained in the Second FGI & Themes Obtained in the Third FGI \\
\hline $\begin{array}{l}\text { Continuing to carry out PACs } \\
\text { (All teachers) }\end{array}$ & $\begin{array}{l}\text { Continuity in PACs use } \\
\text { (All teachers) }\end{array}$ & $\begin{array}{l}\text { Pleasure (All teachers) } \\
\text { Significance of education prior to service (All } \\
\text { teachers) }\end{array}$ \\
Getting material (T2, T5, T7) & Getting new material (T1, T5, T6) &
\end{tabular}

Using outdoor space (T3, T4)

\section{WISHES}

Requesting more activity Sharing (All teachers) Wishing continuity (All teachers)

(All teachers)

Dance and rhythm education (T4, T5, Regular in-service training activities (All teachers) T8)

In the first and second FGIs, the question of "What are your goals and plans for the next month?" was asked to the teachers and they stated that what they would do during the following month as "continuing to carry out PACs, getting material and using outdoor spaces more", and the themes "requesting more activity from the instructor and continuing to share between the teachers" were put forward carrying out the workshop. T6 said in the first FGI about implementation of PACs "We started with the cards now and progressed. We will go on this way, from the easiest to the hardest", and T4 expressed in the second FGI that "To continue moving and being active".

All teachers answered the question "What are your views and suggestions about this study?" directed in the third focus group interview as "We are very pleased and we noticed the importance of pre-service education" and they stated that "such studies about motor field must be continued" and so that other teachers can benefit that "organized in-service training" should be offered. T1 stated about the opinions regarding the workshop that "I am glad that I participated. I don't have any regrets", and T3 emphasized pre-service education and said that "I wish that my undergraduate education had been like this". T5 noted that "It may be a little excessive but can we do this type of training next year or at least more regularly?" and T9 said "We improved ourselves. I wish that all preschool teachers in the city had been here. I think that everyone needs it", and revealed her expectations from the in-service training activities.

\section{Discussion}

In-service training for teachers is defined as the integration of all processes related to gaining professional knowledge, skills, and attitudes and habits so that they can effectively educate students (Budak, 1999). In-service training is carried out to change the behavior of teachers so that they are more innovative and ready to improve their current knowledge and skills so that they can do their jobs more efficiently and can remedy deficiencies in their training. The aim is also to create more unity and solidarity among teachers and to raise their level of motivation, to refresh their knowledge and to keep them up to date with professional and technological developments (Baskan, 2001; cited in Gültekin, Çubukçu \& Dal, 2010).

In the present study, the was aim was that the views of the teachers who participated in this workshop, focused on FMSs and movement concepts would have a positive impact on how they thought about motor development at the preschool level. In this context, the teachers were asked to draw pictures about the games and activities they carry out in their classrooms. It was noted that teachers made the early childhood children of 3-4 years old and 5-6 years of age perform locomotors activities such as mostly walking, running, crawling, rolling and jumping. Moreover, it was also determined that in addition to locomotors movements performed by children of 5-6, the teachers made them perform activities and games (throwing to the target and catching, hula hoop turning, connecting and solving ribbon, and ball games, etc.). At this point, it is clear from the drawings of the teachers that they made children perform a limited number of activities and games in their classrooms. As Özer, Gürkan \& Ramazanoğlu (2006) indicated, play should not be regarded as a means to spend leisure time. However, play is a real and important educational tool to develop imagination and creativity of children and improve their human relationships. Moreover, it is remarkable that very few materials were used in the activities and games included in these drawings. This situation could be as a result of absence of adequate and various materials in schools, limited size of proper activity space, lack of sufficient knowledge and skills of teachers about movement education prior to the workshop, and the teachers not allowing sufficient time for movement education. Similarly, Korkmaz Haşıl \& Erol (2004) reported that the preschool teachers did not use materials such as balls, ropes, etc. in games and didn't prefer using outdoor space for their classes.

The teachers defined movement education at the beginning of the workshop as an education providing physical development, movements helping spiritual and emotional development, activities supporting large-small muscle development, activities with or without tools, and activities providing hand-eye coordination development. When these definitions were analyzed, it was observed that the definitions of the teachers were provided only about a part of the 
FMSs definitions made by Abels \& Bridges (2010) as "movement education is the learning and development of fundamental movement skills by means of movement concepts". The teachers did not include movement concepts in their definitions and this could be due to the exclusion of these concepts in motor field part of the preschool curriculum (MNE, 2013) and they took on the matter during their undergraduate education.

At the beginning of the workshop, the teachers had some difficulties in movement education implementations such as "inadequate physical conditions, absence of material, deficiency of competency and knowledge of the teachers and short attention time of children". The results of study of Sevimli-Çelik \& Johnson (2013) supported this result. Similarly, Sert (2016) explained that the preschool teachers didn't have adequate space and material for movement education in their classes and didn't have adequate knowledge and skills on the matter in her study.

When the focus group interviews about the workshop on movement education were analyzed as a whole, all of the teachers were of the opinion as "they downloaded the yellow group of PACs from internet and used them in their classes" further they noted that "they established communications with all teachers who participated in the workshop". Moreover, the teachers indicated that they increased the variety and time of activities in their classes and they included movement education implementation as planned at least 3 times a week and for 30 minutes. In addition, the teachers pointed out that they used more materials in their applications and tried to find more materials or produce to aid rhythm and dance practices in their classes. Many teachers indicated that they gave movement education before the workshop, however, the number of these applications was generally 1-2 times a week for 5-10 minutes and these were generally fine motor activities (small muscle activities) because of safety reasons. However, NASPE (2002) stated that children in preschool institutions should participate in structured physical activities every day for at least 60 minutes and in unstructured physical activities for 60 to 180 minutes (cited in: Hands \& Martin, 2003). In this context, it was determined that the workshop caused the teachers to make daily activity plan for movement activities in their classes, to recognize PACs which is the assisting and useful tool for movement activities, to allow more time for implementations, and to vary activities and to do more communication and collaboration on this issue with colleague.

Although PACs were developed in Turkey for classroom and physical education teachers working at middle school, yellow card groups consist of FMSs and can be used by preschool teachers. However, it was determined in studies that by giving in-service training to teachers who are going to use PACs, both knowledge and skills of the teachers on this matter were improved, and their professional development enhanced. In addition teachers increased their self-confidence in this area (Spode, 1997, cited in Harris, Cale \& Musson, 2007; Harris, Cale \& Musson, 2011; Harris, Cale \& Musson, 2012). Therefore, in the present study, the teachers stated that knowledge of the PACs (yellow group) was of the best thing they learned from the workshop as well as knowledge about FMS. After their PACs literacy increased, this had an impact on the materials they used in the classroom, the time, amount and type of the activities.

Another important result of the study about changes in the implementations was using an interdisciplinary approach, including different materials and musical games. However, the theme of creating trails, which had fewer rules but included more movement was also noted positively. The teachers indicated that they turned to various and difficult activity implementations and games with more rules in the second and third FGI based on performing movement education practices at least 3 days a week regularly. Meanwhile, the teachers explained that they increased outdoor space (garden) use, their students participated in activities more and they started to use activities and games in their movement activity implementations including and improving gross muscle skills.

The third question directed to the teachers in FGIs was "What are the contributions (your achievements) of the workshop for your students and you personally?". When the answers received from the teachers during all three FGIs are analyzed it was clear that the use of differentiation their classes as they related to movement activities was one of the most positive aspects of the workshop. They also commented on the positive impact of their communication on social media and their opportunity to share their learning. Finally, they expressed their desires to present these new concepts and ideas to local and national authorities in terms of offering seminar. This situation can be perceived as an indicator of increased self-confidence and knowledge/skill competence of the teachers. In addition, the teachers stated that after implementing these new ideas and concepts both they and their students become more active participants. Some teachers stated that they started to use pedometers and participated in some local organizations (tracking, etc.) focused on weight loss. This situation showed that the workshop played a crucial role in fulfilling its purpose because as the teachers developed positive attitude regarding movement education and being active, it is thought that they will try to provide more opportunities for their students in this area. In addition, the teachers expressed that awareness about movement education was one of the real positive features of-the workshop and that it fostered their creativity and problem solving features skills in preparing activities and materials. Similar results were observed in trainings given to class teachers about PACs (Spode, 1997; cited in Harris, Cale \& Musson, 2007; Hunt, 1998; Harris, Cale \& Musson, 2011; Harris, Cale \& Musson, 2012). 
The teachers indicated that their students participated more in the applications, and they became more active and released their energy and became happy. Similar results were reached in many PACs application in different class levels (Harris, Cale \& Musson, 2011; Harris, Cale \& Musson, 2012; Hunt, 1998; Spode, 1997, cited in Harris, Cale \& Musson, 2007; Usluoğlu \& Mirzeoğlu, 2014). In addition, physical activity has a crucial effect on the quality of the future life of children. It is important in the development and protection of their health habits as well (Gallahue \& Ozmun, 1998; Haywood \& Getchell, 2009; Robinson \& Goodway, 2009; cited in Sevimli-Çelik \& Johnson, 2013). Therefore, increasing the activity level of the children in the classes is the good indicator of the effectiveness of the workshop.

Another question asked in the FGIs was "What are the problems you face about implementing the new concepts you learned and how did you solve them?". At the beginning of the workshop, the teachers stated that they lacked sufficient space, materials as well as knowledge/skill competency about movement education. To overcome such problems but they increased their middle and outdoor spaces use as a solution and they did space arrangement in their classes and they attempted to purchase some materials or they designed materials themselves and this could be perceived as a proof that the teachers didn't see these problems as an insurmountable barrier to movement-education. When viewed from this aspect, it can be said that the teachers came to notice problems about movement education and rather than just complain they were able to provide solutions they learned in the workshop.

The teachers were asked in the third FGI that "What are your general views and suggestions about the workshop?" and the answers of the teachers emphasized that this workshop was very useful for them personally and professional life and they were very pleased that they participated. In addition, the teachers expressed that they were going to use the knowledge of this training in their classes in their future professional life, and they stated that continuity of such in-service training activities must be enabled. Moreover, they emphasized that the pre-service education at the universities should be practical and related to the curriculum, and innovations and developments should be kept up by regular in-service training. The views of the teachers about undergraduate education may have been caused by the half of the teachers who participated in the study to be open education faculty graduates.

\section{Conclusion and Suggestions}

In conclusion, based on the information obtained in this study, the workshop that was offered improved knowledge and skill competence of the teachers on movement education and improved their self-confidence regarding teaching these ideas, also helped them to better overcome the problems they faced, enabling them to better design various activities and materials and helping them to become more active individuals. Another important impact of the workshop on the teachers was to encourage them to collaborate and to work on projects jointly. Owing to this communication and collaboration, a common language about movement education was created among the teachers based on the literature and the teachers started to do their activities of gross muscle groups more in their classes and to use outdoor spaces. Furthermore, when the effect of this implementation on the children was explored, it was determined that the children became more active, happier, and participated in movement and games more and obeyed the rules more.

Briefly, it could be said that in reviewing the positive outcomes of the workshop on movement education it is clear that more emphasis needs to be given to this subject in undergraduate university curriculum and in pre-school teacher training institutions. It is suggested that movement education also be included in practicums for new teachers, and arrangements made for of in-service training seminars for existing teachers. All of this could play a crucial role for solving present deficiencies in this area and would lead to real benefits for children's health and their enjoyment of physical activity.

\section{References}

Abels, K. W., \& Bridges, J. M. (2010). Teaching movement education: Foundations for active lifestyles, Human Kinetics, USA.

Australian Bureau of Statistics (2000). Children's participation in cultural and leisure activities, Australia (4901.0 April 2000). Canberra. ACT: Australian Bureau of Statistics.

Budak, Y. (1999). Total quality management in education and the importance of in-service education for techers in the implemantation of an effective school, Journal of Modern Education, 25, 35-38.

Corbin, C. B., \& Pangrazi, R. P. (1998). Physical activity for children: A statement of quidelines. Reston, VA: NASPE.

Department of Education Western Australia. (2013). Fundamental movement skills: Learning, teaching and assessments, Book 1.

Graham, G., Holt/Hale, S., \& Parker, M. (2010). Children moving: A reflective approach to teaching physical education. (8th Edi.), McGraw Hill, NewYork.

Gültekin, M., Çubukçu, Z., \& Dal, S. (2010). In-service training needs of the primary school teachers regarding 
education teaching, SÜ. Ahmet Keleşoğlu Journal of Education Faculty, 29, 131-152.

Hands, B. P., \& Martin, M. (2003). Implementing a fundamental movement skill program in an early childhood setting: The children's perspectives, Australian Journal of Early Childhood, 28(4), 47-52.

Hands, B., Parker, H. E., \& Larkin, D. (2001). Building an active future summit: Background paper. Perth, WA: University of Notre Dame.

Harris, J., Cale, L., \& Muson, H. (2007). Evaluation of the impact of the TOP programmes on teaching and learning in primary schools in England. Loughborough University. England. https://doi.org/10.1080/19415257.2010.531973

Harris, J., Cale, L., \& Muson, H. (2011). The effects of a professional development programme on primary school teachers' perceptions of physical education. Professional Development in Education, 37(2), 291-305. https://doi.org/10.1080/17408989.2011.582489

Harris, J., Cale, L., \& Muson, H. (2012). The predicament of primary physical education: a consequences of "insufficient" ITT and "ineffective" CPD?. Physical Education and Sport Pedagogy, 17(4), 367-381. doi:10.1080/17408989.2011.582489

Hunt, S. (1998). Cross-cultural issues in the use of quality of life measures in randomized controlled trials. M. Staquet, R. Hays and P. Fayers (eds.) Quality of life assessments in clinical trials (p: 51-68). Within, Oxford: Oxford University Press. http://www.uluslararasiilham.org.tr/site/?page_id=82, [Retrieved on February 11, 2013].

Korkmaz Haşıl, N., \& Erol, S. (2004). An investigation on the practice of physical education and sports activities in terms of teacher's educational backgrounds at preschool level (A case at Bursa provience),A.U. Journal of Physical Education and Sport Sciences, 6(3), 8-16.

Miles, M. B., \& Huberman, A. M. (1994). Qualitative data analysis (2nd ed.). Thousand Oaks, CA: Sage Publications.

Ministry of National Education. (2012). Curriculum for game and physical activity course. [Available online at http://www.tegm.meb.gov.tr/dosya/ogretimprogrami.pdf], Retrieved on May 18, 2014.

National Association for Sport and Physical Education. (2002). Active start: A statement of physical activity guidelines for children birth to five years, Reston, VA: NASPE.

Özer, A., Gürkan, A. C., \& Ramazanoğlu, M. O. (2006). The effects of play in children development, Research of Eastern Anatolia Region, 4(3), 54-57.

Özyürek, A., Özkan, İ., Begde, Z., \& Yavuz, N. F. (2015). Physical education and sport in pre-school period, International Journal of Science Culture and Sport (IntJSCS), Special Issue 3, 479-488. https://doi.org/10.14486/IJSCS314

Sert, S. (2016). Investigation of opinions and implementations of pre-school teachers regarding to the field of motor development (Unpublished master's thesis). University of Abant Izzet Baysal, Bolu, Turkey.

Sevimli, S. (2008). Movement education in early childhood education: The views of parents and school administrators (Unpublished master's thesis). Middle East Technical Unıversity, Ankara, Turkey.

Sevimli-Çelik, S., \& Johnson, E. J. (2013). I need to move and so do the children, International Education Studies, 6(5), 1-10. https://doi.org/10.5539/ies.v6n5p1

Usluoğlu, Z., \& Mirzeoğlu, A. D. (2014). Determination of the views of student, parent and physical education teachers regarding TOP cards, 13th International Sport Sciences Congress, 7-9 November, Konya.

Yıldırım, A., \& Simsek, H. (2005). Qualitative research methods in social sciences, Seçkin Publishing, Ankara.

\section{Copyrights}

Copyright for this article is retained by the author(s), with first publication rights granted to the journal.

This is an open-access article distributed under the terms and conditions of the Creative Commons Attribution license which permits unrestricted use, distribution, and reproduction in any medium, provided the original work is properly cited. 